\title{
Erratum to 'Common fixed point theorems for expansion mappings in various abstract spaces using concept of weak reciprocal continuity'
}

Saurabh Manro ${ }^{1 *}$ and Poom Kumam²

\section{"Correspondence:}

sauravmanro@hotmail.com

1school of Mathematics and

Computer Applications, Thapar University, Patiala, Punjab, India

Full list of author information is

available at the end of the article
On critical examination of the results given in our paper [1], we notice one crucial error. We need to carry out the following correction.

Example 1 given in paper [1] is wrong as $g(X) \not \subset f(X)$ because $f(X)=\{2,6\}$ and $g(X)=$ $[2,20]$. So, Example 1 in paper [1] is replaced by the following example.

Example 1 Let $(X, G)$ be a $G$-metric space, where $X=[0,1]$ and

$$
G(x, y, z)=(|x-y|+|y-z|+|z-x|)
$$

for all $x, y, z \in X$.

Define $f, g: X \rightarrow X$ by $f(x)=\frac{x}{2}$ and $g(x)=\frac{x}{6}$ for all $x \in X$.

Then, clearly, $g(X) \subset f(X)$ as $f(X)=\left[0, \frac{1}{2}\right]$ and $g(X)=\left[0, \frac{1}{6}\right]$.

Moreover,

$$
\begin{aligned}
G(f x, f y, f z) & =(|f x-f y|+|f y-f z|+|f z-f x|) \\
& =\frac{3}{2}(|x-y|) \geq q\left[\frac{1}{2}(|x-y|)\right]=q G(g x, g y, g z)
\end{aligned}
$$

for $1<q \leq 3$ and hence, the condition (2.2) of Theorem 2 is satisfied. Also, $f$ and $g$ are two weakly reciprocally continuous self-maps by taking the sequence $\left\{x_{n}=\frac{1}{n}\right\}$. However, the maps are compatible. Thus, all the conditions of Theorem 2 are satisfied and $x=0$ is the unique common fixed point of $f$ and $g$.

Competing interests

The authors declare that they have no competing interests.

Authors' contributions

All authors read and approved the manuscript

Author details

'School of Mathematics and Computer Applications, Thapar University, Patiala, Punjab, India. ${ }^{2}$ Department of Mathematics, Faculty of Science, King Mongkut's University of Technology Thonburi (KMUTT), Bang Mod, Thung Khru, Bangkok, 10140, Thailand.

\section{Springer}

(c) 2013 Manro and Kumam; licensee Springer. This is an Open Access article distributed under the terms of the Creative Commons Attribution License (http://creativecommons.org/licenses/by/2.0), which permits unrestricted use, distribution, and reproduction in any medium, provided the original work is properly cited. 


\section{Acknowledgements}

The authors are grateful to Prof. Ravindra K. Bisht for pointing out some of these errors.

Received: 18 December 2012 Accepted: 22 December 2012 Published: 9 January 2013

\section{References}

1. Manro, S, Kumam, P: Common fixed point theorems for expansion mappings in various abstract spaces using the concept of weak reciprocal continuity. Fixed Point Theory Appl. 2012, 221 (2012). doi:10.1186/1687-1812-2012-22

doi:10.1186/1687-1812-2013-8

Cite this article as: Manro and Kumam: Erratum to 'Common fixed point theorems for expansion mappings in various abstract spaces using concept of weak reciprocal continuity'. Fixed Point Theory and Applications 2013 2013:8.

Submit your manuscript to a SpringerOpen ${ }^{\circ}$ journal and benefit from:

- Convenient online submission

- Rigorous peer review

Immediate publication on acceptance

Open access: articles freely available online

- High visibility within the field

- Retaining the copyright to your article

Submit your next manuscript at $>$ springeropen.com 